\title{
Biodiversity, substrate relationship and distribution of Lichens from Telangana and Andhra Pradesh, India
}

\author{
C. MANOHARACHARY ${ }^{1 *}$ and D. NAGARAJU ${ }^{2}$ \\ ${ }^{1}$ Department of Botany, Osmania University, Hyderabad 500 007, Telangana, India \\ ${ }^{2}$ Department of Botany, Government Degree College, Eturnagaram 506 165, District Jayashankar, Telangana, India
}

Received: 30 May 2017/ Accepted: 20 July 2017/ Published online: 31 August 2017

(C) Indian Phytopathological Society 2017

\begin{abstract}
Lichens are one of the important most viable and successful alliances of photobiont and Mycobiont in nature. Lichens exist in three different growth forms and are distributed throughout the world including in Polar Regions. There is little or no information on lichen floristics, their distribution and substrate relationship from Telangana and Andhra Pradesh states. The survey (2010-13) of different forest localities resulted in the collection of 65 Lichens which have been identified upto species level. The data pertaining to their substrate relationships, growth forms and distribution has been presented.
\end{abstract}

Keywords: Diversity, distribution, growth, lichen, substrate

Nature maintains a number of organisms in its specialized ecological niches. One such symbiotic association of fungus and alga in lichens are nature's most remarkable alliances. A lichen is an association of a fungus and photobionts i.e., algae may be either green algae or cyanobacteria. The mycobiont belongs mostly to Ascomycotina and a few either to Basidiomycotina or Deuteromycotina. However, fungal partners may be necrotrophic or mutualistic. It is also observed that the two fungi may be associated with a single photobiont. There may be 300 genera and 22000 species of obligately lichenicolous fungi with a wide range of biological relationship. Around 2000 lichens are reported from India (Nayaka and Upreti, 2013). It is evidenced that a number of mycobionts are involved in lichens. The number of lichenized fungi is about 14000 and 98 percent of these belong to Ascomycotina. The lichenized membes of Ascomycotina are of Graphidales, Gyalectales, Peltigerales, Pertusariales and Teloshistales. The fungi belonging to Hymenomycetes and Deuteromycetes also contribute for the lichen formation.

Awasthi (1965, 1960, 1988), Awasthi and Joshi (1977, 1978, 1979), Awasthi and Mathur (1987), Awasthi and Singh (1977), Awasthi and Srivastava (1989), Awasthi and Upreti (1980), Pant and Awasthi (1989), Patwardhan and Kulkarni (1977) and Sinha and Singh (2005) have reported lichens covering Himalayas, Sikkim, Madhya Pradesh, Dehra Dun, Andaman areas, Tamil Nadu, Cochin, Bangalore and other areas of India. No attempt is made to understand the floristics of lichens from Telangana and Andhra Pradesh except for rare reports by Awasthi and Srivastava (1989);

\footnotetext{
${ }^{*}$ Corresponding author: cmchary @ gmail.com
}

Manoharachary (1979) and Venugopal Rao and Manoharachary (1980), Oksanen (2006), Karatygin et al. (2007) and Shyamkumar et al. (2011) have elaborated the biology, symbiosis, ecology and biotechnological aspects of lichens. Hariharan (2011) has dealt with conservation of lichens and associated epiphytes to shield the habitats in a changing environment. The above workers emphasized more on the lichen morphology and their taxonomy neglecting substrate relationship, concept of communities and distribution patterns.

The present work forms a significant and an original contribution on the lichen flora associated with some forest localities, their morphology, taxonomy, classification and substrate relationship besides paving the way of exploring the lichen flora from new geographical regions covering some forests of Telangana and Andhra Pradesh. (Ananthagiri Hills (Vikarabad), Yacharam Forest, Nallamalai forest (Srisailam), Tirumala Hills, Ramannapet Hills, Araku valley and Sringavarapu Kota). Type of forests include dry deciduous and scrub jungle forms. Telangana receives $53 \%$ of rainfall and Andhra Pradesh gets around $60-70 \%$.

\section{Topography and climate}

The new State of Telangana has come into existence on June 2, 2014 after nearly six decade long relentless struggle. The state Telangana has an area of $1,14,840$ Sq. $\mathrm{Km}$, bounded by $\mathrm{N}$ latitudes $15^{\circ} 46^{\prime}$ and $19^{\circ} 47^{\prime}$ and E longitudes $77^{\circ} 16^{\prime}$ and $81^{\circ} 43^{\prime}$. The State's geographical area of $1,14,840$ sq. $\mathrm{km}$ holds a population of 351.49 lakhs (2011 Census). Andhra Pradesh, a linguistic state formed in November 1956, ranks fifth in terms of area (1, 60, $205 \mathrm{Sq} . \mathrm{Km})$ in India and lies in between 1240' 
and 1950' North longitude with a population of around six crores, Mainly six types of soils manifest in these two states viz: alluvial soils, black-cotton soils, red soils, laterite soils, arenacious soils and sandy loam soils.

\section{MATERIALS AND METHODS}

The investigations were conducted primarily on Lichen collections during 2010-2013, which were deposited with accession numbers (OULH) in Mycology and Plant Pathology, Department of Botany, Osmania University. Lichenological methods were employed for the identification of lichens. The crystal tests and colour reactions on the thallus and apothecia were tested by $10 \%$ aqueous solutions of potassium hydroxide $(\mathrm{K})$, bleaching powder (calcium hypochlorite-C), iodine (I) and Steiner's paraphenylenediamine (P) (Hale, 1969). Lichen samples were also analysed for their mineral contents (Prasad and Manoharachary, 1993; Hale, 1983; Sinha and Singh, 2005; Nayaka and Upreti, 2013).

\section{RESULT AND DISCUSSION}

\section{Distribution and indicator lichens}

Distribution data of lichens with reference to forest localities have been represented in Table 2. Altogether 65 lichens were collected and were found maximum in A.P.The remaining localities such as Scrub Jungle Forest of Ananathagiri Hills (Vikarabad), Nallamalai Forest Range of Srisailam and Mannanur and also few Scurb Jungle Forest localities of Telangana areas were poorly representated. This data clearly indicates direct correlation between the thickness of vegetation, altitude, rainfall and relative humidity with that of lichen populations. It is also interesting to note that the following are the lichen indicators for different forest localities investigated (Table 1).
Distributions, dominance, quantity of Lichens are dependent on rainfall, temperature, vegetation, Lichen propagule dissemination and growth period.

It is pertinent to mention here that lichens such as Dirinaria applanata D.consimilis, D. picta, Heterodermia dissecta, Lecanora amorpha, Parmelia andina, P. glabra, P. hababiana, P. praesorediosa, Physia alba, Pyxine cocoes, P. petricola and Ramalina confusa have shown greater abundance in the forest localities investigated. These lichens can be considered as bio-indicators. Ecology in modern times has been variously defined. It is the study of reciprocal relations between the organisms and the environment. In an ecological niche, the most tangible element of a plant's environment is its substrate, the material on or in which the lichen grows. In the mycological sense, the substrate often interpreted to mean the nutrive material used by the fungus. However, among lichens, the material supporting lichen thalli is a complex one. Terms such as rock lichens (saxicolous), bark lichens (corticolous) and ground lichens (terricolous) are generally accepted and understood. Identification keys are often based on the substrate classification. The substrate factors such as texture, water relations, chemistry, organic material and temperature affect the lichen substrate ecology. Similar conclusions were drawn earlier by Sinha and Singh (2005) and Tehler (1996).

\section{Substrate relationship}

From the present data (Table 2) it is evident that lichens representing diversified genera namely Buellia, Cladonia, Dirinaria, Graphina, Graphis, Heterodermia, Hyperphyscia, Lecanora, Lecidea, Lecanora, Parmelia, Pertusaria, Physica, Pyxine, Ramalina, Tylophoran and Usnea were found to be cortocolous. It is interesting to note that the saxicolous and terricolous lichens have been poorly represented with rare distribution. Saxicolous

Table 1. Forest localities and lichen indicators

\begin{tabular}{lll}
\hline Sl. No. & Forest locality & Name of the Lichen \\
\hline $\begin{array}{ll}\text { Telangana } \\
\text { 1. }\end{array}$ & Ananthagiri Hills, Vikarabad & Dirinaria picta (Sw.) Clem.\& Shear \\
2. & Yacharam Forest & Pyxine cocoes Nyl. \\
3. & Nallamalai Forest & Pyxine cocoes Nyl. \\
4. & O.U Campus, Hyderabad & Pyxine cocoes Nyl. \\
5. & Nallamalai Forest Range, Srisailam & Parmelia andina Mull.Arg. \\
& & Physcia alba (Fee.) Mull.Arg. \\
Andhra Pradesh & \\
6. & Tirumala Hills & Dirinaria consimillis (Stirton) Awasthi. \\
7. & Karampudi Hills & Parmelia glabra (Schaerer) Nyl. \\
8. & Kondapalli Hills & Leconora amorpha Poelt \\
9. & ArakuValley & Ramalina confuse AwasthiPyxinep etricola Nyl. \\
& & Parmelia hababina Gyelnik \\
10. & Sringavarapukota & Parmelia praesorediosa Nyl. \\
\hline
\end{tabular}


Table 2. Substrate relationship and growth forms in Lichens

\begin{tabular}{|c|c|c|c|c|c|c|}
\hline Name of the lichen & Foliose & Fruticose & Crustose & Substrate & $\begin{array}{l}\text { Accession } \\
\text { No. (OULH) }\end{array}$ & $\begin{array}{l}\text { Forest } \\
\text { locality }\end{array}$ \\
\hline Arthrothelium awasthi Patw. \& Makhija & - & - & + & Bark & 41 & 6,7 \\
\hline Buellia sp. & + & - & - & Bark & 42 & $1,8,9$ \\
\hline Cladonia furcata (Huds.) Schrader & - & + & - & Bark & 43 & $6,7,10$ \\
\hline C. gracilis (L.) Willd. & - & + & - & Bark & 44 & $1,2,3,9$ \\
\hline C. mitis Sandst. & - & + & - & Bark & 45 & $1,4,5,8$ \\
\hline C. rangiferina $(L)$ Weber ex F.H. Wigg & - & + & - & Bark & 46 & $1,6,7,9$ \\
\hline C. tenuis (Florke) Harm & - & + & - & Bark & 47 & $1,3,5,10$ \\
\hline $\begin{array}{l}\text { Coccocarpia erythroxyli (Spreng.) Swinscow } \\
\text { \& Krog. }\end{array}$ & + & - & - & Bark & 48 & $6,7,8$ \\
\hline Dirinaria applanata (Fee.) Awas. & + & - & - & Bark & 49 & 7,10 \\
\hline D. confluens (Fr.) Awas. & + & - & - & Bark & 50 & $1,2,3,9$ \\
\hline D. consimilis (Stirton) & + & - & - & Bark & 51 & $6,7,8$ \\
\hline D. picta (Sw.) Clem. \& Shear & + & - & - & Bark & 52 & $4,5,6,9$ \\
\hline Diorygma megasporum Kalb. Staiger \& Elix & - & - & - & Bark & 53 & $1,9,10$ \\
\hline Dyplolabia afzelii (Ach.) A. Massal & + & - & - & Bark & 54 & $1,2,3,10$ \\
\hline Glyphis cicatricose Ach. & + & - & - & Bark & 55 & $6,7,8,10$ \\
\hline Graphina sp. & + & - & - & Bark & 56 & $3,9,10$ \\
\hline Graphis capillacia Stirt. & - & - & + & Bark & 57 & $5,6,7,9$ \\
\hline Graphis cocarctata Stirt. & - & - & + & Bark & 58 & $1,2,3,9$ \\
\hline Graphis nigroglauca Leight. & - & - & + & Bark & 59 & $4,6,8$ \\
\hline Graphis polystriata Makhija et al. & - & - & + & Bark & 60 & $7,8,9$ \\
\hline $\begin{array}{l}\text { Hemithelium nakanishianum Patw. } \\
\text { \& C.R. Kulkarni }\end{array}$ & - & - & + & Bark & 61 & $1,4,9,10$ \\
\hline Heterodermia boryi (Fee) Kr. P. Singh & + & - & - & Leaf & 62 & $6,7,10$ \\
\hline Heterodermia diadermata (Taylor) D.D.A & + & - & - & Leaf & 63 & $1,2,3,9$ \\
\hline H. dissecta (Kurok) Awas. & + & - & - & Leaf & 64 & $6,7,9$ \\
\hline H. leucomela (L.) Poelt. & + & - & - & Leaf & 65 & $3,8,9,10$ \\
\hline H. podocarpa (Bel.) D.D. Awasthi & + & - & - & Leaf & 66 & $1,4,5,8$ \\
\hline H. pseudospepcicosa (Kurok.) W.L. Culb. & + & - & - & Leaf & 67 & $6,7,9$ \\
\hline $\begin{array}{l}\text { Hyperphyscia adglutinata (Florke) H. Mayrhofer } \\
\text { \& Poelt }\end{array}$ & + & - & - & Bark & 68 & $4,8,9,10$ \\
\hline Lecanora alphoplaca (Wahlend.) Ach. & - & - & + & Bark & 69 & $1,2,6,01$ \\
\hline L. fimbriatula Stirt. & - & - & + & Bark & 70 & $4,5,6,01$ \\
\hline L. indica Zahlbr. & - & - & + & Bark & 71 & $2,8,10$ \\
\hline L. muralis (Schreber) Rabenh. & - & - & + & Bark & 72 & $3,9,10$ \\
\hline Lecidiasp. & - & - & + & Bark & 73 & $1,4,5,01$ \\
\hline Leptogium javanicum Mont. & - & - & + & Bark & 74 & $4,8,9,10$ \\
\hline Letroutia domengensis (Pers). Haf. and Bellem & - & - & + & Bark & 75 & $1,2,3,9$ \\
\hline L. subazureum Dube \& Makhija & - & - & + & Bark & 76 & $1,5,6,7,8$ \\
\hline Parmelia andina Mull. Arg. & + & - & - & Bark & 77 & $3,9,10$ \\
\hline Parmelia caperata (L.) Ach. & + & - & - & Bark & 78 & $8,9,10$ \\
\hline P. crinata Ach. & + & - & - & Bark & 79 & $1,2,3,9$ \\
\hline P. formosana Zalbr & + & - & - & Bark & 80 & $5,6,7,8$ \\
\hline P. glabra (Schaerer) Nyl. & + & - & - & Bark & 81 & $1,2,3$ \\
\hline P. hababiana Gyelink & + & - & - & Bark & 82 & $4,5,6,9$ \\
\hline P. mussoresensis Awas. & + & - & - & Bark & 83 & $1,2,3,10$ \\
\hline P. prasorediosa Nyl. & + & - & - & Bark & 84 & $1,2,3,10$ \\
\hline P. sancte-angelii Lynge & + & - & - & Bark & 85 & $5,6,7,10$ \\
\hline P. tinctorum Despr. Ex Nyl. & + & - & - & Bark & 86 & $4,6,7,9$ \\
\hline
\end{tabular}




\begin{tabular}{|c|c|c|c|c|c|c|}
\hline Name of the lichen & Foliose & Fruticose & Crustose & Substrate & $\begin{array}{l}\text { Accession } \\
\text { No. (OULH) }\end{array}$ & $\begin{array}{l}\text { Forest } \\
\text { locality }\end{array}$ \\
\hline Parmelinella simplicitor (Hale) Elix \& Hale & + & - & - & Bark & 87 & $6,8,9,10$ \\
\hline Parmotrema tinctorum (Nyl.) Hale & + & - & - & Bark & 88 & $6,7,8$ \\
\hline Pertusaria sp. & - & - & + & Bark & 89 & $5,6,7,9$ \\
\hline Pertusaria quassiae (Fee) Nyl. & - & - & -+ & Bark & 90 & \\
\hline Phaeophyscia hispidula (Ach.) Moberg & - & + & - & Bark & 91 & $5,8,9,10$ \\
\hline $\begin{array}{l}\text { Phaeophyscia pyrrophora (Poelt) D.D. Awasthi } \\
\text { \& Joshi }\end{array}$ & - & + & - & Bark & 92 & $6,7,8,9$ \\
\hline Physcia alba (Fee.) Mull. Arg. & - & + & - & Bark & 93 & $6,7,8,10$ \\
\hline Physcia clementei (Sm. in Sm. \& Sow.) Lynge & - & + & - & Bark & 94 & $6,7,8,10$ \\
\hline P. stellaris (L.) Nyl. & + & - & - & Bark & 95 & $1,9,10$ \\
\hline P. tribacia (Ach.) Nyl & + & - & - & Bark & 96 & $3,9,10$ \\
\hline Pyxine cocoes Nyl. & + & - & - & Rock & 97 & $, 1,2,3,9$ \\
\hline P. consocians Vain. & + & - & - & Rock & 98 & $1,5,6,7,9$ \\
\hline P. petricola Nyl. & + & - & - & Rock & 99 & $1,9,10$ \\
\hline Ramalina confuse Awas. & - & + & - & Leaf & 100 & 9,10 \\
\hline Trepethelium eluteriae Spreng. & + & - & - & Bark & 101 & 9,10 \\
\hline Tylophoron moderatum Nyl. & + & - & - & Bark & 102 & $8,9,10$ \\
\hline Usnea sp. & - & + & - & Branch & 103 & $8,9,10$ \\
\hline Usnea complanata (Mull. Arg.) Motyka & - & + & - & Branch & 104 & $8,9,10$ \\
\hline Usnea ghattensis G. Awasthi & - & + & - & Branch & 105 & $8,9,10$ \\
\hline
\end{tabular}

1=Ananthagiri hills; 2=Yacharam; 3=Nallamalai Forest Range, Mannanoor; 4=Osmania University Campus; 5=Srisailam; 6=Tirumala hills; 7 =Karampudi; 8=Kondapalli; 9=Rannapet hills; 10=Araku valley; 11=Sringavarapukota; +=Present; - =Absent; OULH= Osmania University Lichen Herbarium

lichens were represented by Lecanora hellmichiana, Parmelia praesorediosa and Pyxine petricola, Cladonia furcata, $C$. mitis and $C$. rangifernia were recognized as terricolous.

\section{Growth forms}

A number of lichenologists have segregated lichens based on growth forms. Growth form means the overall shape and configuration of the lichen thallus. There are three major types of growth forms: foliose (leaf-like), fruticose (shrubby or hair-like) and crustose (crust-like). Detailed investigations have been made on the collected lichens with special reference to growth forms (Table 2). Altogether 65 lichens were encountered. Out of which 38 are foliose lichens, 12 are fruticose lichens and 15 are crustose lichens. It is interesting to find that the foliose lichens representing Dirinaria, Heterodermia, Hyperphyscia, Parmelia, Physcia and Pyxine formed the dominant lichen flora. Interestingly the lichens have existed mostly in one growth form.

\section{Taxonomy}

Lichen classification seems to be an unsolved problem and needs an indepth analysis and critical evaluation. Though substantial literature has accumulated on lichens from all over the world, the Indian literature is fragmentary. In India, some workers (Awasthi, 1961, 1965, 1973, 1975a,b, 1976, 1980,1981a,b,1988; Awasthi and Joshi1977, 1978; Awasthi and Singh1973,1975; Awashthi and Uperti1980; Patwardhan and Kulkarni1977a,b; Roychoudhury1977 and Singh (1973) have surveyed the forest localities and prepared a checklist of lichens for limited geographical regions. Awashthi (1973, 1975a, b, 1976, 1980, 1981a,b, 1986, 1988) has been an active researcher in the field of lichenology and contributed significantly to the lichen flora of some areas in India and Nepal. His contributions have been outstanding for lichen genera such as Pyxine, Dirinaria, Anaptychia, Heterodermia, Lepogium, Phaeographiana and Rhizocarpon. It is pertinent to mention here that the study of lichen flora has been neglected in Telangana and Andhra Pradesh but for randamised reports (Manoharachary, 1979; Venugopalrao and Manoharachary, 1980). Therefore, an attempt has been made to survey the lichen flora existing in some forest localities of Telangana and Andhra Pradesh. Three years survey (2010-2013) revealed the richness of 65 lichens collected from eleven forest localities. The collected lichens were represented by seventeen generea viz., Buellia, Cladonia, Dirinaria, Graphina, Graphis, Heterodermia, Hyperphyscia, Lecanora, Lecidea, Letrouitia, Parmelia, Pertusaria, Physcia, Pyxine, Ramalina, Tylophoron and Usnea of which, Parmelia was the dominant genus followed by Cladonia, Lecanora, Physcia, Dirinaria, Heterodermia, Graphis and Pyxine. All the collected lichens from new additions to the lichen flora of Telangana and Andhra Pradesh.

The earlier lichenologists have identified the lichens based on spore types, structure of fruit bodies and type 

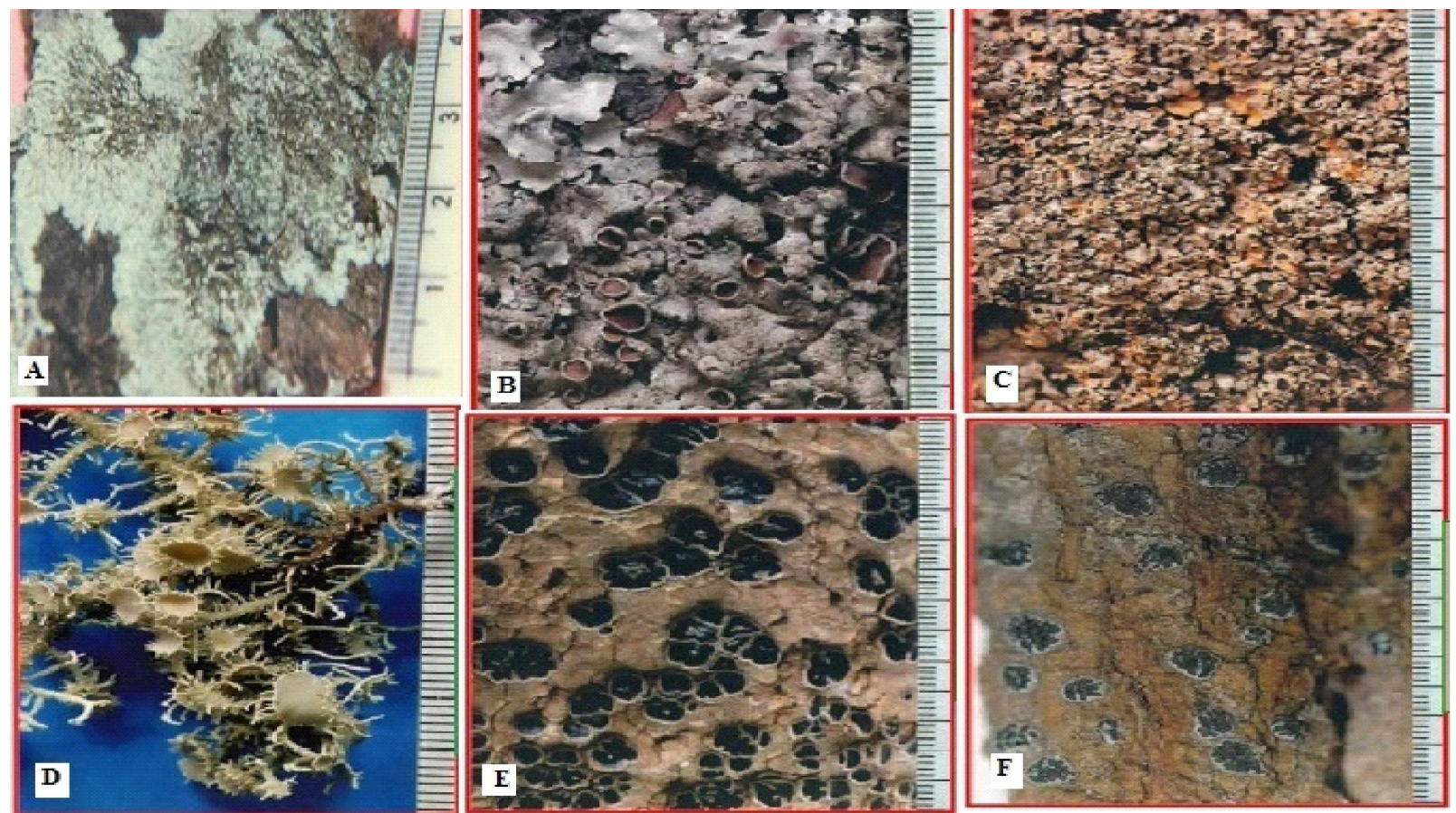

Fig. 1. (A). Dirinaria applanata (Fee.) Awas., (B). Parmelinella simplicitor (Hale) Elix \& Hale., (C). Phaeophysciapyrrophora (Poelt)., D. Awasthi \& Joshi, (D). Usnea ghattensis G. Awasthi., (E). Lecanora fimbriatula Strirt., (F). Glyphis cicatricose Ach.

of alga. Most of the lichen systematists were not familiar with the fungal groups. There is voluminous literature dealing with the vascular plants but much to be gained with references to lichens. Chemical tests, crystal tests, morphology, anatomy, growth form and reproductive structures were the parameters used by different workers (Awasthi1980; Culberson and Kristinsson1970; Hale 1969 Hawksworth and Hill 1988) in identifying the lichens. In the present investigation, similar criteria was also used in the identification of forty eight lichen species. Though a number of classifications are proposed (Hale, 1983; Haleand Culberson, 1970; Poelt, 1973a,b; Zahbruckner, 1926), no commonness was observed for foliose, fruticose and crustose growth forms, respectively.

\section{ACKNOWLEDGEMENTS}

C. Manoharachary is thankful to NASI, Allahabad and A.B. Rajithasri to DST-INSPIRE for awarding fellowship and encouragement.

\section{REFERENCES}

Awasthi DD (1960). Contributions to the lichen flora of India and Nepal. 1. The genus Physcia (Ach.) Vain. J. Indian Bot. Soc. 39: I-21.

Awasthi DD (1961). Some foliose and fruticose lichens from Assam and North-East Frontier Agency of India. Proc. Indian. Acad. Sci. 54: 24-44.

Awasthi DD (1965). Catelogue of lichens from India, Nepal, Pakistan and Ceylon. Beih. Nova. HEDW. 17: 1-137.

Awasthi DD (1973). On the species of Anaptychia and Heterodermia from India and Nepal. Geophytol. 3: 113116.

Awasthi DD (1975a). Lichen flora of Pindari Glacier Valley, India. Geophytol. 5: 178-185.
Awasthi DD (1975b). A monograph of the lichen genus Dirinaria. Bibliot. H. Lichenol. 2: 1-108.

Awasthi DD (1976). Lichen genus Parmelia in India. Sub genera Paremelia in India Sub genera Parmelia and Amphigymnia. Biol Memoirs Lucknow. 1: 155-229.

Awasthi DD (1981a). The typification of Roccella montagnei. Bryologist 84: 216-219.

Awasthi DD (1981b). Lichen genus Parmelia inIndia 2 .Sub genera Xanthoparmelia (Vain.) Haleand Melanoparmelia (Heu) Essel. Indian J. For. 4: 198-204.

Awasthi G (1986). The lichen genus Usnea from India and Nepal. J. Hattori Bot. Lab. 61: 333-421.

Awasthi DD (1988). Two interesting lichen taxa new to India. Curr. Sci. 57: 146

Awasthi DD and Joshi M (1977). Macro lichens of Mussoorie Hills, Uttar Pradesh. Geophytology 7: 91-97.

Awasthi DD and Joshi M (1978). Contribution to the lichen flora of Chakrata Hills, Uttar Pradesh, India. Indian J. Mycol. Res. 16: 273-278.

Awasthi DD and Joshi M (1979). The lichen genera Helminthocarpon, Cyclographa and Cyclographina (gen. Nov.). Norw. J. Bot. 26: 164-177.

Awasthi DD and Mathur R (1987). Species of the lichen genera Bacidia, Badimia, Fallhanera and Mycobilimbia from India. Proc. Indian Acad. Sci. (Plant Sci.) 97: 481-503.

Awasthi DD and Singh KP (1973). Species of the lichen genus Phaeographina in Indian Subcontinent. Kavaka 1: 87-98.

Awasthi DD and Singh KP (1975). Observations on some Graphidaceous lichen taxa. Phyta. 1: 34-40.

Awasthi DD and Singh SR (1977). The lichen genus Rhizocarpon (Ram) Th. Fr. in India. Kavaka 5: 49-58.

Awasthi DD and Srivastava P (1989). Lichen genera Brigantiaea and Letrouitia from India. Proc. Indian Acad. Sci. (Plant Sci.). 99: 165-177. 
Awasthi DD and Upreti DK (1980). A note on lichens from Lalbagh Garden, Bangalore. Indian J. Bot. 3: 181-184.

Culberson CF and Kristinsson H (1970). A. standardized method for the identification of lichen products. J. Chromatogr. 46: 85-93.

Hale ME (1983). 'The Biology of Lichens.' London; pp. 1-190

Hale ME (1969). 'The Lichens W. M. C. Brown Company Publishers, lowa: pp. 1-226.

Hale ME and Culberson WL (1970). Fourth checklist of the lichens of the continental United States and Canada. Bryologist 73: 499-543.

Hariharan GN (2011). Conservation of lichens and associated epiphytes to shield the habitats in a changing environment. Abstracts of Recent Advances in Mycological Research, $37 \mathrm{MSI}$ Meeting Madras University Chennai.

Hawksworth DL and Hill DJ (1988). The Lichen Forming Fungi. Chapman \& Hall, NY.

Lamb IM (1977). A conspectus of the lichen genus Sterecaulon (Schreb) Hoffim. J. Hattori. Bot. Lab. J. 43: 191-355.

Karatgin IV, Srigirevskaya NS and Vikulin SV (2007). Two types of symbiosis with participation of fungi from Early Devonian ecosystems. XVCongress of European Mycologists Saint Petersburg Russia, Sept 16-21 1: 226.

Manoharachary C (1979). Parmelia hababiana Gyel. A new record for Andhra Pradesh, India. Geobios 6: 48.

Nayaka Sanjeeva and Upreti DK (2013). Lichens of Uttar Pradesh, U.P State Biodiversity Board Publ. Lucknow, pp. 175.

Okasanen (2006). Ecological and biotechnological aspects of lichens. Appl. Microbiol. Biotechnol. 73: 723-734.
Pant G (nee Awasthi) and Awasthi DD (1989). Lichen genus Catillaria sp. lat. in India. Proc. Indian Acad. Sci. (Plant. Sci.) 99: 369-384.

Patwardhan PG and Kulkarni CR (1977). Some additions to the Lichen flora of India - V. Genera Phaeographis and Phaeographina (Family: Graphidaceae). Curr. Sci. 46: 720721.

Patwardhan PG and Kulkarni CR (1977). A contribution to our knowledge of the lichen flora of India-I. Family. Thelotremataceae. Kavaka 5: 1-17.

Poelt J Classification. In: Ahmadjian V and ME (1973). Hale (eds), 'TheLichens' Academic press, New York: pp. 599632.

Prasad U and Manoharachary C (1993). Mineral Composition of Pyxinecocoes Nyl. Bio. J. 5: 5-6.

Roychowdhury KN (1977). Unrecorded species of lichens from India. Bull. Bot. Surv. India 15: 132-136.

Shyamkumar R, Tajuddin N and Upreti DK (2011). Diversity of lichens in Kolli hills of Tamil Nadu. Int. J. Biodiversity Conservation. 3: 36-39.

Singh KP (1973). Additions to the lichen flora of India-II, Kavaka I: $43-46$.

Sinha GP and Singh KP (2005). Botanical Survey of India, MOENF. pp. 273.

Tehler A (1996). Systamatics, Phylogeny and classification. In: Nash TH III (ed.) Lichen biology. Cambridge University Press, Cambridge. pp. 217-239.

Venugopal Rao K and Manoharachary C (1980). Additions to the lichen flora of Andhra Pradesh, India. Geobios 7: 176.

Zahlbruckner A (1926). Lichens (Flecten) in Engler and Prantl, Die Naturlichen Pflanzen familien, Leipzig. 8: 1 -270. 